\title{
Motion - Genetic testing is useful in the diagnosis of nonhereditary pancreatic conditions: Arguments against the motion
}

\author{
Jonathan A Cohn MD
}

JA Cohn. Motion - Genetic testing is useful in the diagnosis of nonhereditary pancreatic conditions: Arguments against the motion. Can J Gastroenterol 2003;17(1):53-55.

\begin{abstract}
Mutations of two genes, the cystic fibrosis transmembrane conductance regulator gene (CFTR) and the pancreatic secretory trypsin inhibitor gene (PSTI), are associated with an increase in the risk of idiopathic chronic pancreatitis. Persons who have mutations of both CFTR alleles (one severely and one mildly affected) are especially susceptible to this disease. Because these compound heterozygotes have sufficient residual CFTR function, they do not develop cystic fibrosis lung disease. One PSTI mutation, N34S, independently increases the risk of pancreatitis. Thus, the risk of pancreatitis is greatest among individuals who are CFTR compound heterozygotes and who also have the PSTI mutation. Nonetheless, most people with CFTR and PSTI mutations do not develop pancreatitis. This fact indicates that environmental influences and gene-gene interactions also affect pancreatitis risk. Although CFTR and PSTI genetic testing can identify persons at an increased risk of pancreatitis, there are several reasons why the routine screening of individuals with nonhereditary pancreatitis is not recommended at this time: most disease-associated mutations are not detected by readily available techniques, genetic counselling guidelines do not exist, most patients with mutations do not develop pancreatitis and the results of testing do not affect the clinical management of pancreatitis.
\end{abstract}

Key Words: Cystic fibrosis; Cystic fibrosis transmembrane conductance regulator; DNA mutational analysis; Genetic predisposition to disease; Kazal pancreatic; Pancreatitis; Polymorphism (genetics); Trypsin inhibitor
L'analyse génétique est utile pour le diagnostic de maladies pancréatiques non héréditaires : Arguments contre cette proposition

RÉSUMÉ : La présence de mutations dans deux gènes, le gène régulateur de la perméabilité transmembranaire de la fibrose kystique (CFTR, cystic fibrosis transmembrane conductance) et le gène inhibiteur de la trypsine pancréatique (PSTI, pancreatic secretory trypsin inhibitory), est associée à un risque accru de pancréatite chronique idiopathique. Les personnes dont les deux allèles du CFTR portent des mutations (une grave et l'autre bénigne) sont particulièrement vulnérables à l'égard de cette maladie. Comme il reste une fonction CFTR résiduelle suffisante chez ces hétérozygotes, la fibrose kystique pulmonaire ne se manifeste pas. La mutation N34S du PSTI augmente de manière indépendante le risque de pancréatite. Par conséquent, celui-ci est plus élevé chez les personnes qui sont hétérozygotes à l'égard du CFTR et dont le PSTI porte également une mutation. Toutefois, la plupart des personnes ayant des mutations dans le CFTR et le PSTI ne font pas de pancréatite, ce qui indique que l'environnement et les interactions entre gènes influent également sur le risque de cette maladie. Bien que l'analyse génétique du CFTR et du PSTI permette de repérer les personnes particulièrement à risque de pancréatite, le dépistage systématique des personnes souffrant de pancréatite non héréditaire n'est pas recommandé à l'heure actuelle pour les raisons suivantes : les techniques courantes ne permettent pas de détecter la plupart des mutations associées à la maladie; il n'y a aucune ligne directrice pour le counselling génétique; la plupart des patients présentant des mutations ne font pas de pancréatite; et les résultats n'influent pas sur la prise en charge clinique de la pancréatite.
$\mathrm{D}$ uring the past few years, several groups have shown that the risk of nonhereditary pancreatitis is increased in those individuals who have mutations of the cystic fibrosis transmembrane conductance regulator gene (CFTR) and of a trypsin inhibitor gene (PSTI, also known as the serine protease inhibitor, Kazal type 1 gene) (1-12). The present article reviews the evidence linking pancreatitis with mutations of these two genes, and discusses the rationale and limitations of CFTR and PSTI genetic testing in the diagnosis of nonhereditary pancreatitis.

Idiopathic chronic pancreatitis (ICP) is the leading cause of chronic pancreatitis in children and nonalcoholic adults. Because most cases are sporadic, genetic factors were not ini- tially implicated in its pathogenesis. Nonetheless, three facts suggest that CFTR mutations might predispose to ICP: the earliest pathological finding in ICP often consists of plugging of the smaller pancreatic ducts which is reminiscent of the early findings in cystic fibrosis. ICP can cause sweat test abnormalities and pancreatitis is a rare complication of cystic fibrosis (with a lifetime incidence of 1\%) (2). These considerations led two groups to test ICP patients for CFTR mutations $(1,2,12)$. A total of 86 subjects with ICP were studied, and 20\% had common cystic fibrosis-causing CFTR mutations. This is approximately five times the expected prevalence of cystic fibrosis carriers.

This article was originally presented at a symposium entitled, "Controversies in Gastroenterology", sponsored by Axcam Pharma, Toronto, Ontario, April 8 to 10, 2002

Division of Gastroenterology, Duke University Medical Center, Durham North Carolina 27710-001, USA

Correspondence: Dr JA Cohn, Division of Gastroenterology, Duke University Medical Center, 314 Sands Building, Box 3378,

Durham, North Carolina 27710-001, USA. Telephone 919-684-6879, fax 919-684-4983, e-mail cohn0001@mc.duke.edu 
On average, cystic fibrosis carrier status increases the risk of ICP by five-fold. This is important, because 3\% to $4 \%$ of white people in the United States are carriers $(2,13)$. Because fewer than $1 \%$ of these carriers develop ICP, a key question is whether all carriers are at similar risk for ICP. To address this question, Noone et al (12) recently tested a series of ICP patients with common CFTR mutations to determine whether the other copy of the gene was also abnormal. In most cases, the authors found an atypical or uncommon mutation involving the other copy of the gene. The subjects with ICP each had one CFTR mutation with virtually no function (eg, causing over $98 \%$ loss of function) together with a milder mutation of the other copy of their gene (eg, causing an $80 \%$ loss of function). These compound heterozygous genotypes are associated with a $90 \%$ reduction of CFTR function, which explains why these individuals do not develop cystic fibrosis lung disease. The amount of residual CFTR function - roughly 10\% of normal - is sufficient to protect these patients from lung injury. ICP risk is increased about 50 -fold in individuals with these compound heterozygous genotypes.

The large increase in ICP risk strongly implicates defective CFTR function in the pathogenesis of ICP. At least 95\% of CFTR compound heterozygotes, however, do not develop ICP. Thus, unlike cystic fibrosis lung disease, ICP exhibits non Mendelian (or complex) inheritance (Table 1). Virtually all

\section{TABLE 1}

Cystic fibrosis versus idiopathic chronic pancreatitis

\begin{tabular}{|c|c|c|}
\hline $\begin{array}{l}\text { Distinguishing } \\
\text { feature }\end{array}$ & Classic CF & Classic ICP \\
\hline $\begin{array}{l}\text { Typical CFTR } \\
\text { genotype }\end{array}$ & CFsev/CFsev & CFsev/CFm- \\
\hline $\begin{array}{l}\text { Residual CFTR } \\
\text { function }\end{array}$ & $<5 \%$ & $5 \%-25 \%$ \\
\hline Penetrance & $>95 \%$ & $<10 \%$ \\
\hline Inheritance & Mendelian & Complex \\
\hline Effect of genotype & $\begin{array}{l}\text { Causes } \\
\text { disease }\end{array}$ & $\begin{array}{l}\text { Increases } \\
\text { disease risk }\end{array}$ \\
\hline $\begin{array}{l}\text { Gene-environment and } \\
\text { gene-gene interactions }\end{array}$ & Minor role & Major role \\
\hline
\end{tabular}

CF Cystic fibrosis; CFm-v Mutations causing mild or variable loss of function; CFsev Mutations causing virtually complete loss of function; CFTR Cystic fibrosis transmembrane conductance regulator gene; ICP Idiopathic chronic pancreatitis individuals with two cystic fibrosis-causing mutations develop cystic fibrosis (13). In contrast, CFTR compound heterozygosity increases the risk of ICP, but does not always cause the disease. One implication of this finding is that environmental influences and gene-gene interactions might be important in determining which individuals are susceptible to develop ICP.

One mutation of the PSTI gene (N34S) has also been associated with many forms of pancreatitis $(8,14)$. The N34S PSTI mutation occurs in roughly $1 \%$ of the general population, and it increases the risk of pancreatitis by 20 -fold $(12,14)$. Because pancreatitis does not develop in $99 \%$ of individuals who harbour N34S, the inheritance pattern is also non Mendelian.

Additional studies have shown that the N34S PSTI mutation is not associated with autosomal dominant hereditary pancreatitis (15). On the other hand, one recent report indicates that N34S is associated with ICP in individuals who have CFTR mutations. For CFTR compound heterozygotes who also have N34S, the risk of ICP was increased by 900 -fold (12). The additive impact of CFTR and PSTI mutations on pancreatitis risk is consistent with the fact that these genes are expressed at different sites in the exocrine pancreas: CFTR occurs mainly in the apical membrane of duct cells $(16,17)$, while PSTI occurs maily in the zymogen granules of acinar cells (4).These data imply that PSTI genetic testing might help to identify CFTR compound heterozygotes who are at especially high risk for ICP. Even when PSTI and CFTR mutations are both present in a single individual, however, the risk of developing ICP is still less than 50\%.

From a practical standpoint, CFTR and PSTI genetic testing may be useful in selected individuals with unexplained pancreatitis. It can help patients to understand their disease, and it can allow earlier recognition of extra-pancreatic CFTRrelated problems that may be associated with ICP (eg, male infertility). In addition, it can identify cystic fibrosis carriers who may benefit from genetic counselling, and it can identify rare patients with cystic fibrosis in whom pancreatitis is the initial clinical problem. In most patients with CFTR mutations, the amount of residual CFTR protein function can be predicted from the genotype and this correlates with the clinical diagnosis (Table 2).

However, there are important limitations to CFTR and PSTI genetic testing for the diagnosis of pancreatitis. First, most patients with CFTR-related ICP have uncommon or atypical mutations that cannot be detected using genetic testing methods that are currently available for clinical use. This means that caution is required when a clinical testing lab

TABLE 2

Cystic fibrosis transmembrane conductance regulator gene (CFTR) genotypes correlate with clinical diagnoses

\begin{tabular}{lccc}
\hline & PI-CF & PS-CF & CBADV, ICP \\
\hline CFTR mutations & Severe + severe & Severe + milder & Severe + mild-variable \\
Residual CFTR function (\%) & $0-2$ & $2-5$ & $5-20$ \\
Pancreatic insufficiency & Typical & Rare & Severe + wild type \\
Abnormal sweat test & Typical & Typical & Unexpected \\
CF lung disease & Typical & Typical & Variable \\
CBAVD & Typical & Typical & Rare \\
Pancreatitis & Absent & $10 \%$ & $<30 \%$ \\
\hline
\end{tabular}

CBAVD Congenital bilateral absence of the vas deferens; CF Cystic fibrosis; ICP Idiopathic chronic pancreatitis; PI Pancreatic insufficiency; PS Pancreatic sufficiency 
reports a nondiagnostic mutational analysis. Second, genetic counselling guidelines do not exist for individuals who have either normal or abnormal results. Third, most patients with mutations of the CFTR and/or PSTI genes do not develop ICP. Genetic testing is thus unable to definitively predict who will develop ICP, even though it can identify persons who are at increased risk. Finally, the results of CFTR and PSTI testing do not affect clinical management of pancreatitis at this time. For these reasons, it seems premature to recommend CFTR and PSTI genetic testing as routine procedures during the diagnostic evaluation of nonhereditary pancreatitis.

\section{REFERENCES}

1. Sharer N, Schwarz M, Malone G, et al. Mutations of the cystic fibrosis gene in patients with chronic pancreatitis. N Engl J Med 1998;339:645-52.

2. Cohn JA, Friedman KJ, Noone PG, Knowles MR, Silverman LM, Jowell PS. Relation between mutations of the cystic fibrosis gene and idiopathic pancreatitis. N Engl J Med 1998;339:653-8.

3. Arduino C, Gallo M, Brusco A, et al. Polyvariant mutant CFTR genes in patients with chronic pancreatitis. Clin Genet 1999;56:400-4.

4. Naruse S, Kitagawa M, Ishiguro H. Molecular understanding of chronic pancreatitis: A perspective on the future. Mol Med Today 1999;5:493-9.

5. Choudari CP, Lehman GA, Sherman S. Pancreatitis and cystic fibrosis gene mutations. Gastroenterol Clin N Am 1999;28:543-9.

6. Castellani C, Bonizzato A, Rolfini R, Frulloni L, Cavallini GC, Mastella G. Increased prevalence of mutations of the cystic fibrosis gene in idiopathic chronic and recurrent pancreatitis. Am J Gastroenterol 1999;94:1993-5.

7. Liddle RA, Cohn JA. Hereditary diseases of the pancreas. In: Yamada
T, Alpers DH, Owyang C, Powell DW, Silverstein FE, eds. Textbook of Gastroenterology, 3rd edn. New York: JB Lippincott, 1999:2229-43.

8. Witt H, Luck W, Hennies HC, et al. Mutations in the gene encoding the serine protease inhibitor, Kazal type 1 are associated with chronic pancreatitis. Nat Genet 2000;35:213-6.

9. Cohn JA, Bornstein JD, Jowell PS. Cystic fibrosis mutations and genetic predisposition to idiopathic chronic pancreatitis. Med Clin North Am 2000;84:621-31.

10. Ockenga J, Stuhrmann M, Ballmann M, et al. Mutations of the cystic fibrosis gene, but not cationic trypsinogen gene, are associated with recurrent or chronic idiopathic pancreatitis. Am J Gastroenterol 2000;95:2061-7.

11. Etemad B, Whitcomb DC. Chronic pancreatitis: Diagnosis, classification, and new genetic developments. Gastroenterology 2001;120:682-707.

12. Noone PG, Zhou Z, Silverman LM, Jowell PS, Knowles MR, Cohn JA. Cystic fibrosis gene mutations and pancreatitis risk: Relation to epithelial ion transport and trypsin inhibitor gene mutations. Gastroenterology 2001;121:1310-9.

13. Rosenstein BJ, Cutting GR. The diagnosis of cystic fibrosis: A consensus statement. Cystic Fibrosis Foundation Consensus Panel. J Pediatr 1998;132:589-95.

14. Pfutzer RH, Barmada MM, Brunskill AP, et al. SPINK1/PSTI polymorphisms act as disease modifiers in familial and idiopathic chronic pancreatitis. Gastroenterology 2000;119:615-23.

15. Ockenga J, Dork T, Stuhrmann M. Low prevalence of SPINK1 gene mutations in adult patients with chronic idiopathic pancreatitis. J Med Genet 2001;38:243-4.

16. Cohn JA, Melhus O, Page LJ, Dittrich KL, Vigna SR. CFTR: Development of high-affinity antibodies and localization in sweat gland. Biochem Biophys Res Commun 1991;181:36-43.

17. Marino CR, Matovcik LM, Gorelick FS, Cohn JA. Localization of the cystic fibrosis transmembrane conductance regulator in pancreas. J Clin Invest 1991;88:712-6. 


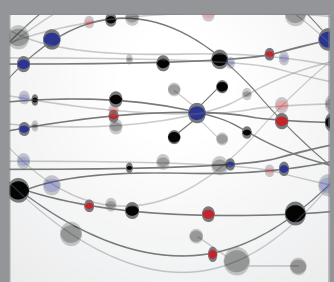

The Scientific World Journal
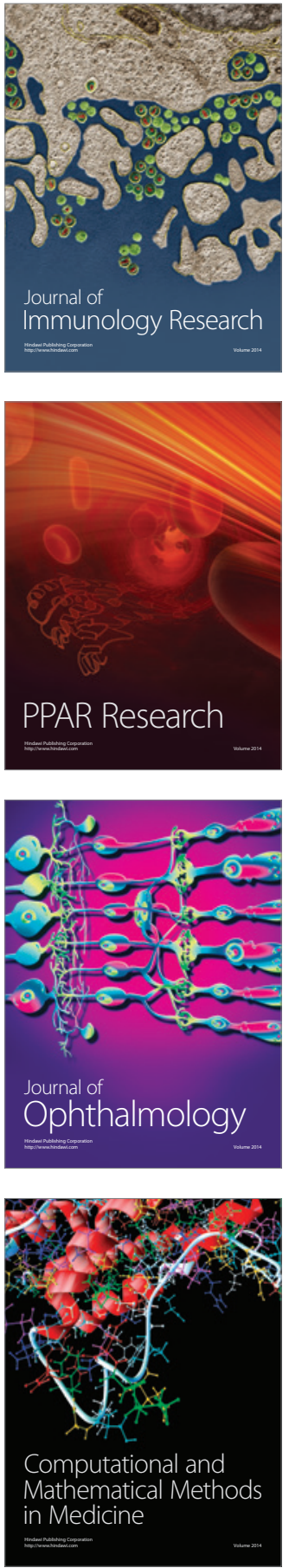

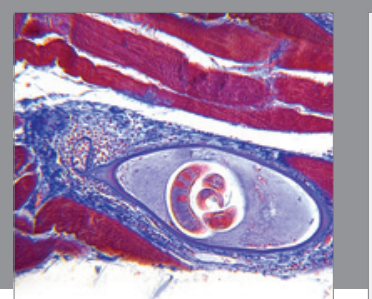

Gastroenterology Research and Practice

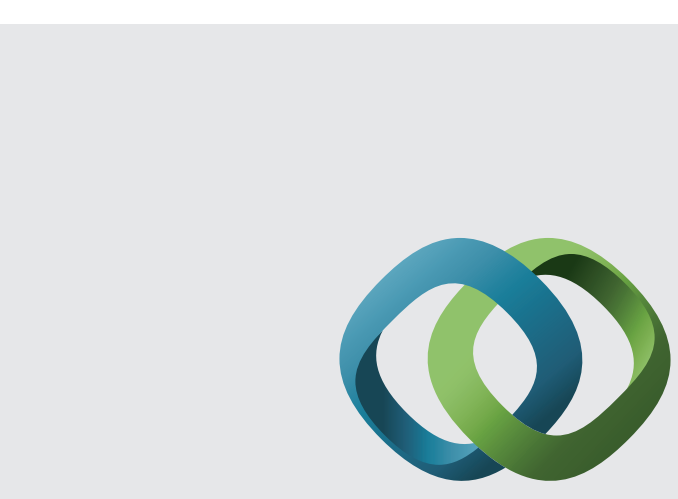

\section{Hindawi}

Submit your manuscripts at

http://www.hindawi.com
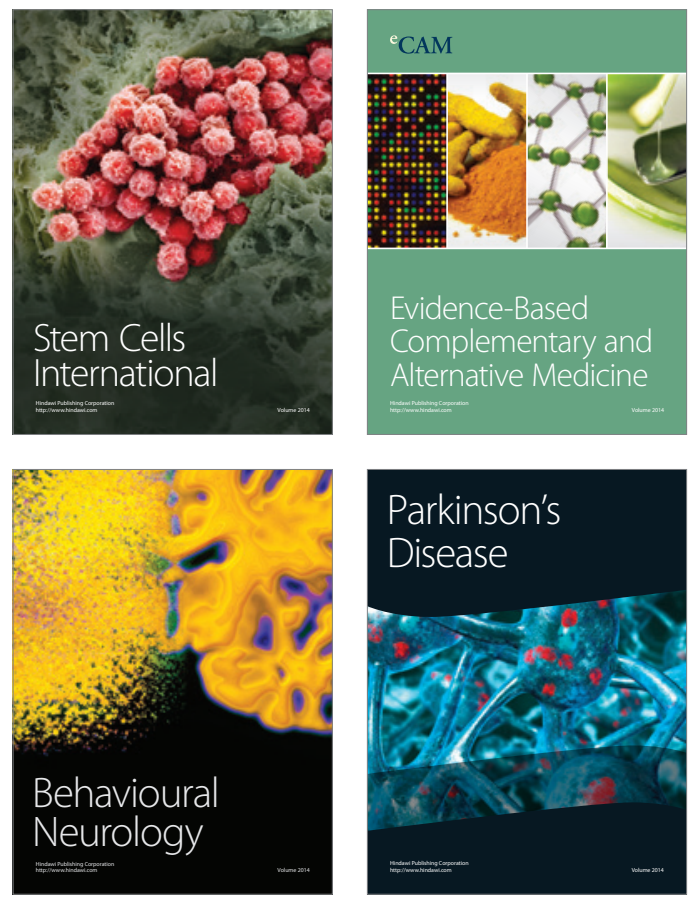
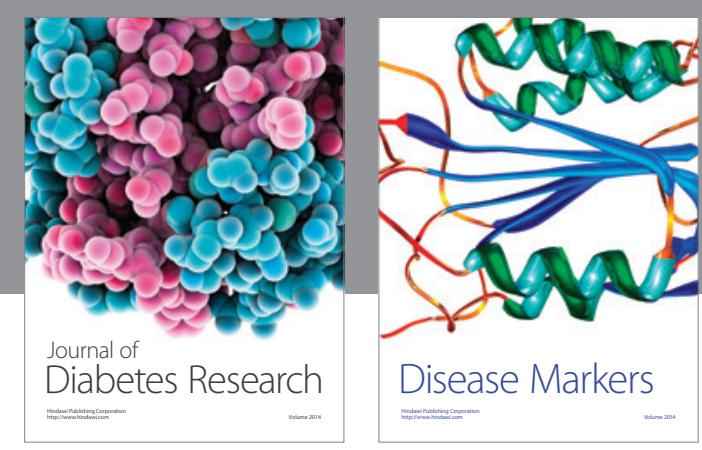

Disease Markers
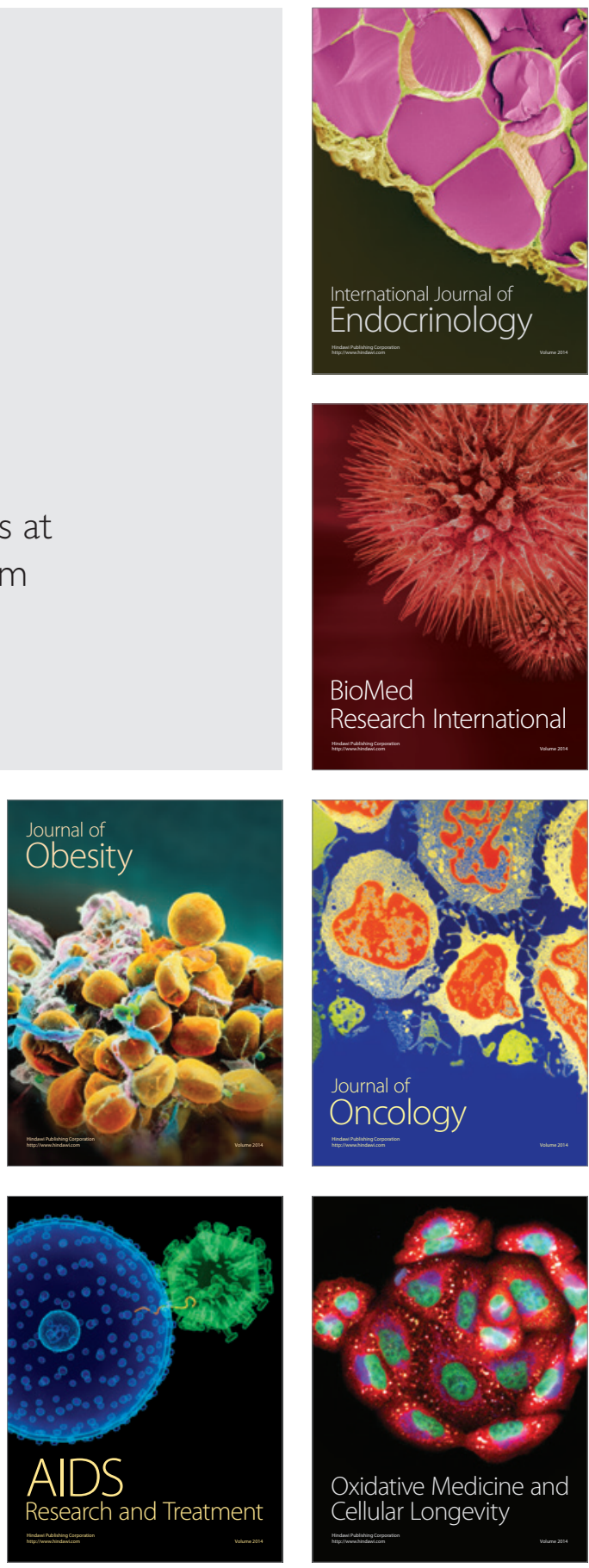